\title{
Torsional Strength Prediction of RC Hybrid Deep T-Beam with an Opening using Softened Truss Model
}

\author{
Lisantono, A. ${ }^{1}$, Besari, M. S. ${ }^{2}$, and Suhud, R. ${ }^{2}$
}

\begin{abstract}
This paper presents an analytical study to predict the torsional behavior of reinforced concrete (RC) hybrid deep T-beam with opening and to compare to the experimental results. The RC hybrid deep T-beam was cast with normal weight concrete web and light weight concrete flanges. Based on the Softened Truss Model and Bredt's theory, a new equation was derived and proposed to show the relationship between compression strut of light weight concrete and normal weight concrete. Based on the experimental results of cracking angles and curvature equation of light weight concrete and normal weight concrete, a new equation was also proposed to show the relationship between strain diagram of light weight concrete and normal weight concrete. The analytical results show that the prediction of maximum torque capacity of the beams are close to the experimental results, except the prediction of twist angle which are larger than the experimental results.
\end{abstract}

Keywords: Pure torsion, RC hybrid deep T-beams, softened truss model, torque capacity, twist angle.

\section{Introduction}

In order to pass utility (ducts and pipes) and also to save headroom, an opening is often required in the beam. Beam with opening subjected to pure torsion is very rare. Normally it is subjected to combination of bending, shear and torsion. However, it is important to study the beam under pure torsion as the basis of understanding their complex behavior under combine loadings [1]. Researches in torsion of shallow beam were extensively carried out [2-8], however, research in torsion of deep beams is rare and attracts little attention. Beams with span/depth ratios about four or less are categorized as deep beams [9]. Akhtaruzzaman and Hasnat [10] conducted investigation on the torsional behavior of deep beams with and without opening, while Samman et al [11] reported their investigations on the torsional behavior of rectangular plain concrete deep beams without opening.

Lisantono et al. [12] has reported preliminary investigation on the effect of light weight concrete (LWC) flanges and web opening on the torsional capacity of RC deep T-beams. Lisantono et al. [13,14] also investigate the effect of web opening locations,

\footnotetext{
${ }^{1}$ Department of Civil Engineering, Universitas Atma Jaya Yogyakarta, Yogyakarta, INDONESIA.

Email: adelisantono@mail.uajy.ac.id

2 Department of Civil Engineering, Institut Teknologi Bandung, Bandung, INDONESIA
}

Note: Discussion is expected before June, $1^{\text {st }} 2013$, and will be published in the "Civil Engineering Dimension" volume 15, number 2, September 2013.

Received 17 November 2011; revised 26 July 2012; accepted 15 February 2013 in horizontal as well as in vertical direction, on the torsional behavior of RC deep T-beam. To obtain a clear understanding on the effect of web opening dimension on the torsional behavior of RC hybrid deep T-beams, Lisantono et al [15] conducted an experimental program. This study aims to develop a method for predicting the torsional capacity of RC hybrid deep T-beam, especially deep T-beam with web opening.

\section{Softened Truss Model Theory}

A beam subjected to pure torsion will behave as an analogous thin wall tube-space truss [2-6]. After the beam cracks, concrete strut will be subjected to compression force and the reinforcement acts as a tie. Hsu [16] stated that three equilibrium conditions of Truss Model satisfy Mohr's stress circle and by assuming that the steel bars can only resist axial stresses, superposition of concrete stresses gives:

$$
\begin{aligned}
& \sigma_{l}=\sigma_{d} \cos ^{2} \alpha+\sigma_{r} \sin ^{2} \alpha+\rho_{l} f_{l} \\
& \sigma_{t}=\sigma_{d} \sin ^{2} \alpha+\sigma_{r} \cos ^{2} \alpha+\rho_{t} f_{t} \\
& \tau_{l t}=\left(-\sigma_{d}+\sigma_{r}\right) \sin \alpha \cos \alpha
\end{aligned}
$$

where

$\sigma, \sigma_{t}=$ normal stresses in the direction of longitudinal steel bar (the 1 direction) and the direction of transverse steel bar (the $t$ direction), respectively (positive for tension)

$\tau_{t}=$ shear stresses in the l-t coordinate (positive as shown in Figure 1)

$\sigma_{d}, \sigma_{r}=$ principal stresses in the $\mathrm{d}$ and $\mathrm{r}$ directions, respectively (positive for tension) 
$\alpha \quad=$ angle of inclination of the d-axis with respect to $l$ axis

$\rho_{l}, \rho_{t}=$ reinforcement ratios in the 1 and $\mathrm{t}$ directions as $\frac{A_{l}}{p_{0} t_{d}}$ and $\frac{A_{t}}{s t_{d}}$

$f_{l}, f_{t}=$ steel stresses in the 1 and $\mathrm{t}$ - directions, respectively

$A_{l}, A_{t}=$ area of total longitudinal steel bars and area of one leg of stirrup, respectively.

$p_{0} \quad=$ periphery of shear flow center line

$s \quad=$ stirrups spacing

According to the Bredt's theory which stated the shear flow should be constant along the centerline of the shear flow zone and can be related to the torque, T. Hsu [4] adding one more equilibrium equation:

$T=\tau_{l t}\left(2 A_{0} t_{d}\right)$

where

$T=$ torque

$A_{0}=$ the area within the centerline of the shear flow

$t_{d}=$ the effective thickness of shear flow
Hsu [16] showed that from the compatibility condition of the truss model, the average strains satisfy the Mohr's strain circle and gives the following equations:

$\varepsilon_{l}=\varepsilon_{d} \cos ^{2} \alpha+\varepsilon_{r} \sin ^{2} \alpha$

$\varepsilon_{t}=\varepsilon_{d} \sin ^{2} \alpha+\varepsilon_{r} \cos ^{2} \alpha$

$\gamma_{l t}=2\left(-\varepsilon_{d}+\varepsilon_{r}\right) \sin \alpha \cos \alpha$

where

$\varepsilon l, \varepsilon_{t}=$ average strains in the $\mathrm{l}$ and $\mathrm{t}$ directions, respectively (positive for tension)

$\eta_{t}=$ average shear strains in the l-t coordinate (positive as shown in Figure 1)

$\varepsilon_{d}, \varepsilon_{r}=$ average principal strains in the $\mathrm{d}$ and $\mathrm{r}$ directions, respectively (positive for tension)

The stress and strain of concrete in the d direction follows material law proposed by Vecchio and Collin [17] for the softened concrete:

$\sigma_{d}=\zeta f_{c}^{\prime}\left[2\left(\frac{\varepsilon_{d}}{\zeta \varepsilon_{0}}\right)-\left(\frac{\varepsilon_{d}}{\zeta \varepsilon_{0}}\right)^{2}\right]$ for $\left|\varepsilon_{d}\right| \leq\left|\zeta \varepsilon_{0}\right|$



(a) Definitions of stresses and coordinate system



(b) Superposition of concrete stresses and steel stresses

Figure 1. Stress Condition in Reinforced Concrete Element [16] 
$\sigma_{d}=\zeta f_{c}^{\prime}\left[1-\left(\frac{\frac{\varepsilon_{d}}{\varepsilon_{0}}-\zeta}{2-\zeta}\right)^{2}\right]$ for $\left.\left|\varepsilon_{\mathrm{d}}\right|\right\rangle\left|\zeta \varepsilon_{0}\right|$

with

$\zeta=\sqrt{\frac{\varepsilon_{d}}{(1-\mu) \varepsilon_{d}-\varepsilon_{r}}}$

where

$\sigma_{d}=$ compression stress at the concrete strut

$\zeta=$ softening coefficient

$\mu=$ Poisson rasio

$\varepsilon_{0}=$ strain at the maximum compressive stress of nonsoftened concrete and can be taken as $0.002[4]$.

Hsu [7] used the softening coefficient as proposed by Belarbi and Hsu [18] as follows:

$\zeta=\frac{0.9}{\sqrt{1+600 \varepsilon_{r}}}$

The stress-strain relationship in the $r$ direction can be expressed by

$$
\begin{aligned}
& \sigma_{r}=E_{c} \varepsilon_{r} \text { for } \varepsilon_{r} \leq \varepsilon_{c r} \\
& \sigma_{r}=\frac{f_{c r}}{1+\sqrt{\frac{\varepsilon_{r}-\varepsilon_{c r}}{0.005}}} \text { for } \varepsilon_{r}>\varepsilon_{c r}
\end{aligned}
$$

where

$E_{c}=$ modulus of elasticity of concrete

$\varepsilon_{c r}=$ strain at cracking of concrete, taken to be $\frac{f_{c r}}{E_{c}}$

$f_{c r}=$ stress at torsional cracking of concrete is assumed to occur when the principal tensile stress reaches the tensile strength of the concrete in biaxial tension-compression and can be taken as $\frac{1}{3} \sqrt{f_{c}^{\prime}}$

[19]

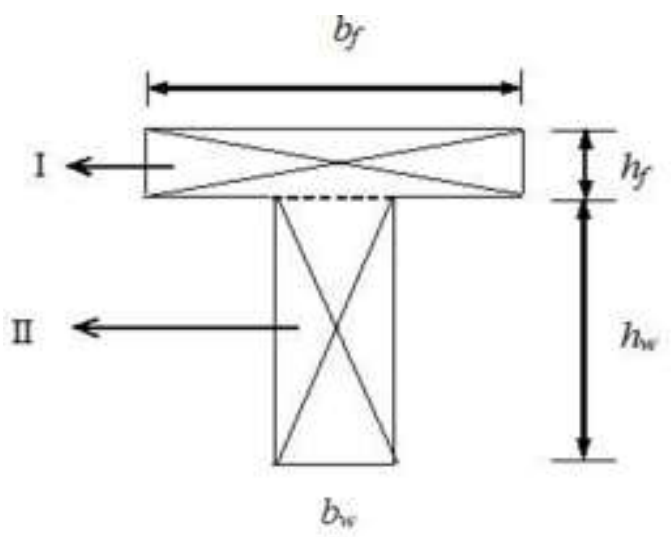

(a) Torque proportion without opening
The stress-strain relationship for longitudinal and transverse steel bars are assumed to be elasticperfectly plastic.

\section{Softened Truss Model for RC Hybrid Deep T- beam}

According to CEB-FIP Model Code 1990 [20] for beam consisting of several rectangular sections, the torque of the beam can be assumed to be distributed on each rectangular section as:

$T_{i}=T \frac{X_{i}^{3} Y_{i}}{\sum X_{i}^{3} Y_{i}}$

where

$T=$ total torque

$T_{i}=$ torque that assumed to be resisted by the-ith section

$X_{i}=$ the smaller size of the $-\mathrm{i}^{\text {th }}$ section

$Y_{i}=$ the larger size of the-ith section

The RC hybrid deep T-beam in this research was cast of normal weight concrete web and light weight concrete flanges as shown in the Figure 2.a.

If the flange portion and web portion are denoted as I and II, respectively, the proportion of each torque becomes:

$T_{I}=T \frac{h_{f}^{3} b_{f}}{\left(b_{w}^{3} h_{w}+h_{f}^{3} b_{f}\right)}$

$T_{I I}=T \frac{b_{w}^{3} h_{w}}{\left(b_{w}^{3} h_{w}+h_{f}^{3} b_{f}\right)}$

Considering the web opening in the beam (Figure 2.b), Equation 12 and 13 become:

$T_{I}=T \frac{h_{f}^{3} b_{f}}{\left\{b_{w}^{3}\left(h_{w}-d_{0}\right)+h_{f}^{3} b_{f}\right\}}$



(b) Torque proportion with opening

Figure 2. Torque Proportion of the RC Hybrid Deep T-beam 
$T_{I I}=T \frac{b_{w}^{3}\left(h_{w}-d_{0}\right)}{\left\{b_{w}^{3}\left(h_{w}-d_{0}\right)+h_{f}^{3} b_{f}\right\}}$

where

$T=$ total torque

$T_{I}=$ torque resisted by flange (light weight concrete)

$T_{I I}=$ torque resisted by web (normal weight concrete)

$b_{f}=$ width of flange

$h_{f}=$ thickness of flange

$b_{w}=$ width of web

$h_{w}=$ height of web

$d_{0}=$ opening diameter
To derive the torque capacity of a $\mathrm{RC}$ hybrid deep Tbeam after cracking the beam is assumed to be a space truss-thin wall tube analog as shown in Figure 3. Figure 3 shows that the shear flow of flange section (light weight concrete) is qI and the effective thickness of shear flow zone is $t_{d I}$, while the shear flow and the effective thickness of web section (normal weight concrete) are qII and $t_{\mathrm{dII}}$, respectively. Taking a small element $\mathrm{A}$ at flange section and $\mathrm{B}$ at web section of the RC hybrid deep T-beam as shown in Figure 3, the shear stress of element A will be:

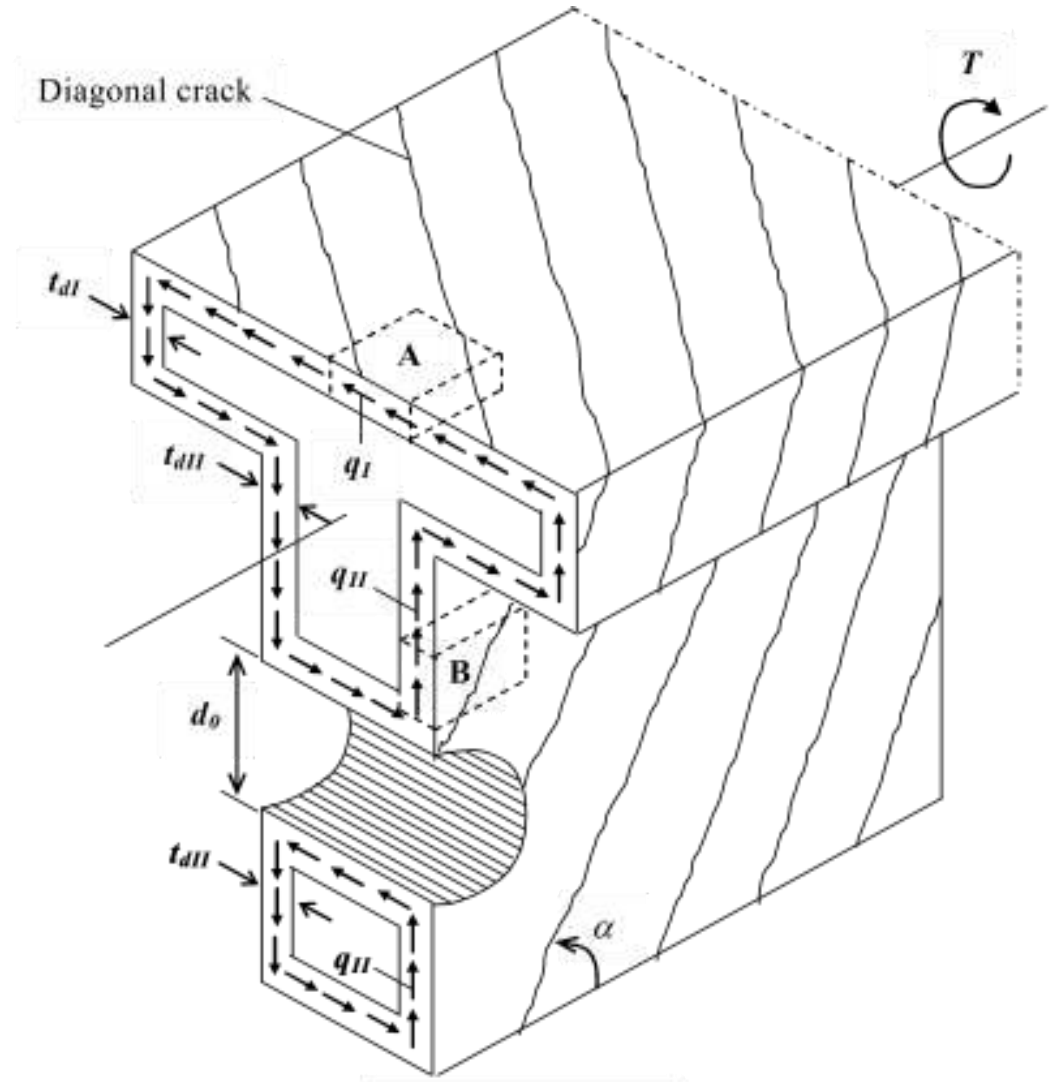

(a) General view



Element A

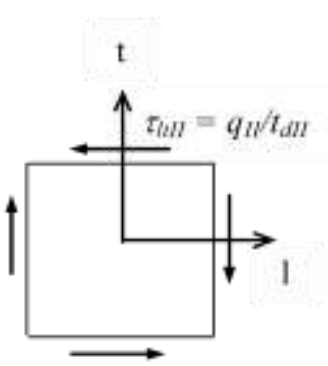

Element B

(b) Shear flow zone element A and B in $1-t$ coordinate

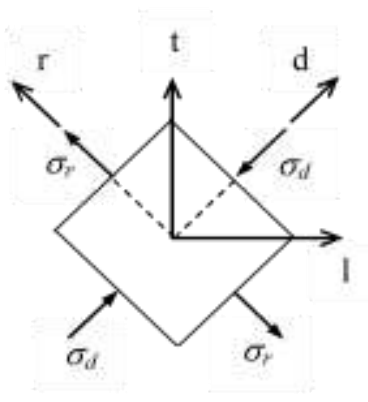

(c) Shear flow zone element in $\mathrm{d}-\mathrm{r}$ coordinate

Figure 3. Space Truss-Thin Wall Tube Analogy for RC Hybrid Deep T-beam with Opening 


$$
\tau_{l t I}=\frac{q_{I}}{t_{d I}}
$$

Therefore, the shear flow in the flange section is

$$
q_{I}=\tau_{l t I} t_{d I}
$$

Similarly the shear stress and shear flow of element $\mathrm{B}$ in web section are;

$$
\begin{aligned}
& \tau_{l t I I}=\frac{q_{I I}}{t_{d I I}} \\
& q_{\text {II }}=\tau_{\text {ltII }} t_{d I I}
\end{aligned}
$$

According to the Bredt's theory [4] the shear flow $q$ must be constant along the shear flow center line. Therefore, the relationship of shear flow of light weight and normal weight concrete can be obtained as:

$$
q_{I}=q_{I I}
$$

Substituting Equations 17 and 19 into Equation 20 gives:

$$
\tau_{l t I} t_{d I}=\tau_{l t I I} t_{d I I}
$$

Assuming that the stress and strain of the light weight and normal weight concrete satisfy the equilibrium condition of membrane element (Equation 3), gives the relationship at the light weight and normal weight concrete as

$$
\begin{aligned}
& \tau_{l t I}=\left(-\sigma_{d I}+\sigma_{r I}\right) \sin \alpha_{I} \cos \alpha_{I} \\
& \tau_{l t I I}=\left(-\sigma_{d I I}+\sigma_{r I I}\right) \sin \alpha_{I I} \cos \alpha_{I I}
\end{aligned}
$$

Hsu [5] stated that as long as the tensile strength $\left(\sigma_{r}\right)$ of the concrete is very small compared to the compressive strength $(\sigma d)$, the effect on the torque will be small too. Therefore, the tensile strength $\left(\sigma_{r}\right)$ can be neglected in the analysis. Substituting $\sigma_{r I}=$ $\sigma_{r I I}=0$ into Equations 22 and 23, gives

$$
\begin{aligned}
& \tau_{l t I}=-\sigma_{d I} \sin \alpha_{I} \cos \alpha_{I} \\
& \tau_{l t I I}=-\sigma_{d I I} \sin \alpha_{I I} \cos \alpha_{I I}
\end{aligned}
$$

Substituting Equations 24 and 25 into Equation 21 gives

$$
-\sigma_{d I} \sin \alpha_{I} \cos \alpha_{I} t_{d I}=-\sigma_{d I I} \sin \alpha_{I I} \cos \alpha_{I I} t_{d I I}
$$

Experimental results [12-15] show that diagonal cracking angle of the light weight and normal weight zone is the same, hence:

$$
\alpha_{I}=\alpha_{I I}=\alpha
$$

Therefore, Equation 26 can be reduced as

$-\sigma_{d I} t_{d I}=-\sigma_{d I I} t_{d I I}$
Equation 28 illustrates that the compressive force at the strut of light weight concrete must be in equilibrium condition with the compressive force at the strut of normal weight concrete. Therefore, if the characteristics of light weight and normal weight concrete are not the same, the effective thickness of shear flow zone or $t_{d}$ must not be the same either.

Lampert and Thurlimann [21,22] proposed that due to warping, the strut concrete is not only subjected to compressive force but also flexure at the tube wall. This phenomenon can be stated in curvature equation as:

$\psi=2 \theta \sin \alpha \cos \alpha$

where,

$\psi=$ curvature of concrete strut

According to the flexural phenomenon at the tube wall, the curvature of concrete strut at each light weight and normal weight concrete can be obtained as:

$$
\begin{aligned}
& \psi_{I}=\theta_{I} 2 \sin \alpha_{I} \cos \alpha_{I} \\
& \psi_{I I}=\theta_{I I} 2 \sin \alpha_{I I} \cos \alpha_{I I}
\end{aligned}
$$

Due to the composite condition of the light weight and normal weight concrete, therefore the twist angle of the light weight concrete is the same as the twist angle of the normal weight concrete, hence

$\theta_{\mathrm{I}}=\theta_{\mathrm{II}}=\theta$

Considering that $\alpha_{I}=\alpha_{I I}=\alpha$ (Equation 27) and $\theta_{I}=$ $\theta_{I I}=\theta$ (Equation 32), Equation 30 is the same with Equation 31, therefore giving

$\psi_{I}=\psi_{I I}=\psi$

Equation 33 implies that the curvature at the light weight concrete strut is the same as the curvature at the normal weight concrete strut, hence the strain diagram block of light weight concrete strut in the flanges and normal weight concrete strut in the web of the beam can be plotted as shown in Figure 4.

Since $\psi_{I}=\psi_{I I}=\psi$, it can be obtained that (see Figure 4):

$\frac{\varepsilon_{d s I}}{t_{d I}}=\frac{\varepsilon_{d s I I}}{t_{d I I}}$

If $\varepsilon_{d s I}=2 \varepsilon_{d I}$ and $\varepsilon_{d s I I}=2 \varepsilon_{d I I}$ (see Figure 4), Equation 34 can be rewritten as:

$\frac{\varepsilon_{d I}}{t_{d I}}=\frac{\varepsilon_{d I I}}{t_{d I I}}$ 


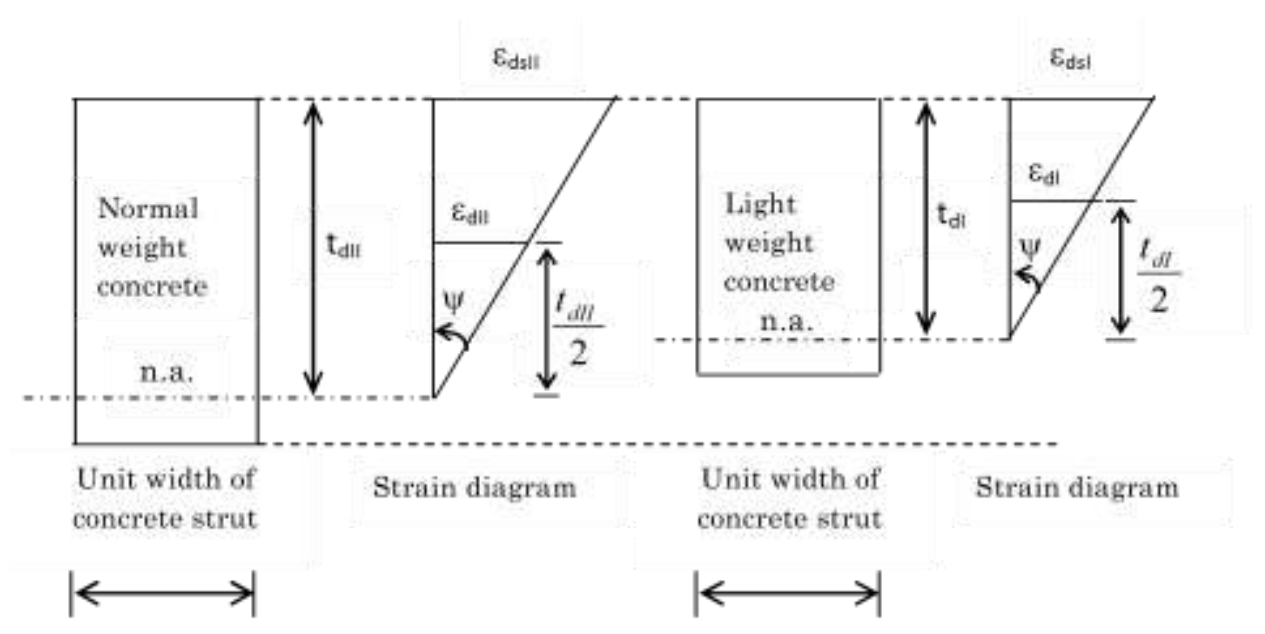

Figure 4. Curvature at the Strut of Light Weight and Normal Weight Concrete


Figure 5. Flow Chart of Calculation of RC Hybrid Deep T-beam Torque

Based on Equations 27, 28, 32, 33; and Equation 35 the softened truss model for RC hybrid deep T-beam with web opening can be developed [23]. By using FORTRAN, the flow chart of calculation to predict the torque capacity of RC hybrid deep T-beam with web opening can be seen in Figure 5.
It is to be noted that program was terminated when $\varepsilon_{d I}$ has reached the value of 0.00175 or $\varepsilon_{d s I}=0.0035$, where $\mathcal{E}_{d s I}$ is the compression strain of concrete at the outer surface of diagonal concrete strut, while $\varepsilon_{d I}$ is the compression strain of concrete at the middle height of the effective thickness of the diagonal concrete strut (see Figure 4). 


\section{Experimental Program}

To verify the theory, Lisantono et al [15] conducted experimental program of torsional $\mathrm{RC}$ hybrid deep- $\mathrm{T}$ beams. Four beams namely B4HS; B4HOD1; B4HO; and B4HOD3 were prapared. The first beam (B4HS) was reinforced concrete hybrid deep T-beam without opening, cast of normal weight concrete web and light weight concrete flanges.
The second, third and fourth beams (B4HOD1; $\mathrm{B} 4 \mathrm{HO}$ and B4HOD3) were reinforced concrete hybrid deep T-beams with web opening diameters of $100 \mathrm{~mm} ; 200 \mathrm{~mm}$ and $300 \mathrm{~mm}$, respectively. The circular openings were located at mid span and mid depth of the beam. All beams have the same span of $2000 \mathrm{~mm}$ and the same nominal cross-sectional dimensions. Details of the beams are shown in Figures 6, 7, 8, and 9.
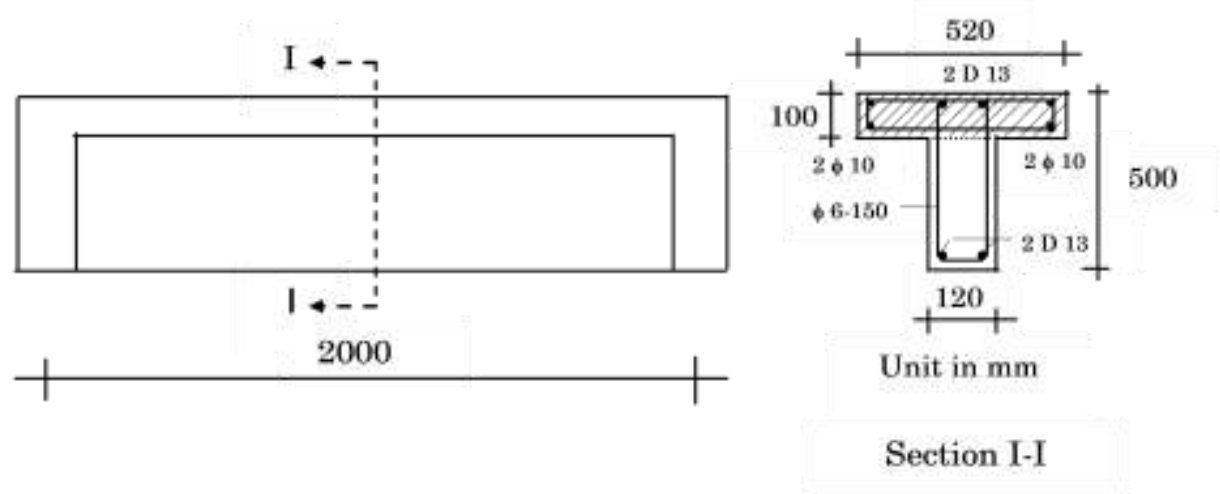

Figure 6. Specimen B4HS
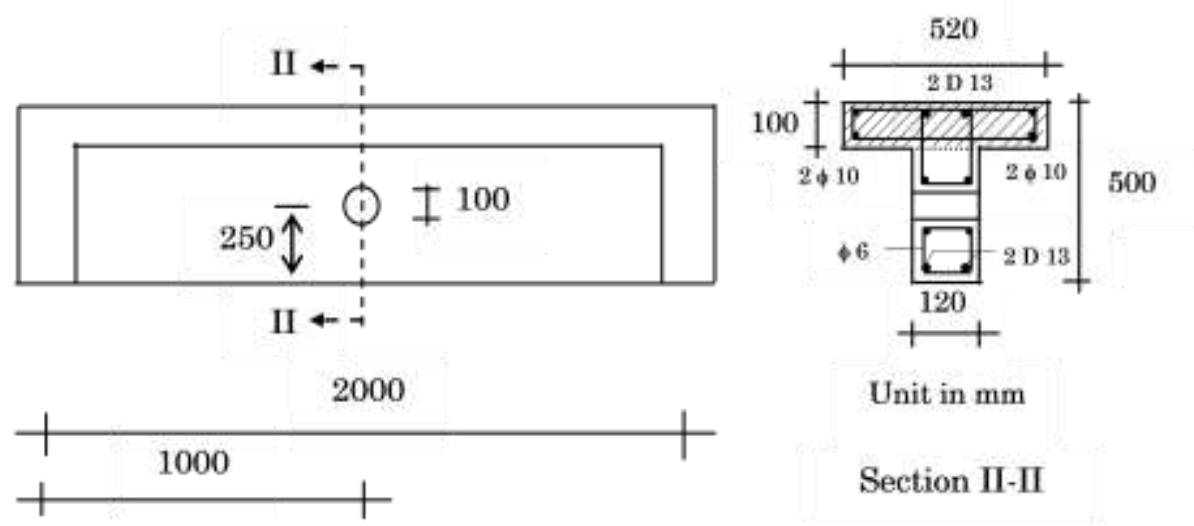

Figure 7. Specimen B4HOD


Figure 8. Specimen B4HO 


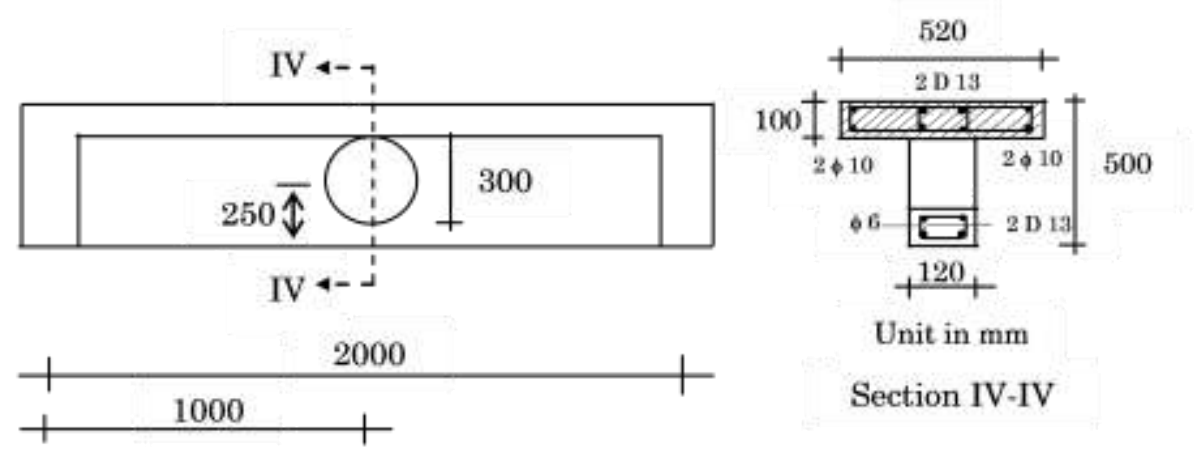

Figure 9. Specimen B4HOD3

B4HS and $\mathrm{B} 4 \mathrm{HO}$ were cast out of batches different from those of B4HOD1 and B4HOD3. The mechanical properties of the concrete are shown in Table 1.

Table 1. The Properties of Concretes

\begin{tabular}{crrrr}
\hline \multirow{2}{*}{ Specimen } & \multirow{2}{*}{ B4HS \& B4HO } & \multicolumn{2}{c}{ B4HOD1 \& } \\
& \multicolumn{1}{c}{ B4HOD3 } \\
\hline Concrete & \multicolumn{1}{c}{ NWC } & \multicolumn{1}{c}{ LWC } & \multicolumn{1}{c}{ NWC } & \multicolumn{1}{c}{ LWC } \\
\hline Density $\left(\mathrm{kg} / \mathrm{m}^{3}\right)$ & 2356.96 & 1721.98 & 2374.20 & 1780.65 \\
$\mathrm{f}_{\mathrm{c}}(\mathrm{MPa})$ & 35.40 & 40.74 & 35.68 & 40.03 \\
$\mathrm{f}_{\mathrm{sp}}(\mathrm{MPa})$ & 3.32 & 2.79 & 3.41 & 2.76 \\
$\mathrm{E}_{\mathrm{c}}(\mathrm{GPa})$ & 25.15 & 14.70 & 26.04 & 15.57 \\
$\mu$ (Poisson ratio) & $0.18-0.22$ & $0.18-0.26$ & $0.19-0.26$ & $0.19-0.23$ \\
\hline
\end{tabular}

The test setup of the specimen is illustrated in Figure 10. The beams were instrumented for measurements of prevailing deflections and rotations. The deflections and rotations due to the torque force were measured using LVDT and inclinometers respectively. The electrical resistance strain gauges were used to measure strains in reinforcements and concrete.

\section{Results and Discussion}

Comparison between the experimental results and the softened truss model theory of the beam B4HS, B4HOD1, B4HO, and B4HOD3 can be seen in Figures 11, 12, 13, and 14, respectively.

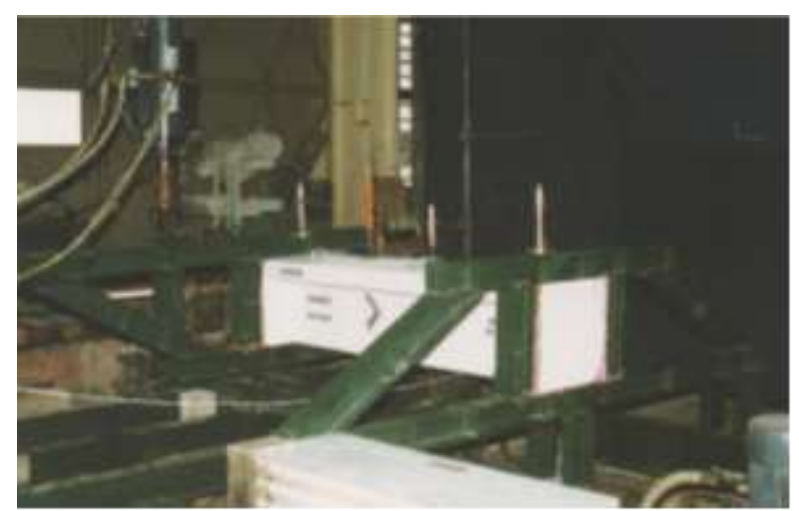

Figure 10. Test Setup of the Specimen
The experimental results show that generally the strength characteristics of the tested beams up to first cracking behave essentially linear. After first cracking, preceded by a small drop in torque, the curves increased non-linearly with increasing twist up to their ultimate torque. It was observed that the small drop in torque occurred when the crack propagated a short distance along the corner line of the web-flange interface. After reaching their ultimate torque, the curves decreased non-linearly with increasing twist, and proceeded with a section of an approximately horizontal plateau, indicating a state of yielding prior to collapse [15].

Figures 11, 12, 13, and 14, show that the theory can predict not only the torsional strength of the $\mathrm{RC}$ hybrid deep-T beam, but also the angle of twist throughout the post-cracking loading history. Comparing to the experimental results, it can be seen that generally the stiffness of the tested beam is stiffer than the curve predicted by the theory. To evaluate the accuracy of proposed theory, the torque capacity and twist angle predicted by the proposed theory were compared to the experimental results. Comparison of the maximum torque capacity based on the proposed theory with the experimental results can be seen in Table 2 .

Table 2. Comparison of the Maximum Torque Capacity

\begin{tabular}{cccccc}
\hline Number & Beam & $\begin{array}{c}\mathrm{T}_{\text {ult }}(\text { anl.) } \\
(\mathrm{kNm})\end{array}$ & $\begin{array}{c}\mathrm{T}_{\text {ult }}(\mathrm{exp} .) \\
(\mathrm{kNm})\end{array}$ & $\begin{array}{c}\mathrm{T}_{\text {ult(anl)/ }} / \\
\mathrm{T}_{\text {ult(exp) }}\end{array}$ & $\begin{array}{c}\text { Diffe- } \\
\text { rences } \\
(\%)\end{array}$ \\
\hline 1 & B4HS & 14.310 & 14.697 & 0.974 & 2.6 \\
2 & B4HOD1 & 14.293 & 14.246 & 1.003 & 0.3 \\
3 & B4HO & 13.582 & 13.660 & 0.994 & 0.6 \\
4 & B4HOD3 & 11.850 & 12.317 & 0.962 & 3.8
\end{tabular}

$\overline{\mathrm{T}_{\text {ult }}(\mathrm{anl} .) \text { : } \text { maximum torque capacity based on the softened }}$ truss model

Tult (exp.): maximum torque capacity based on experimental program 


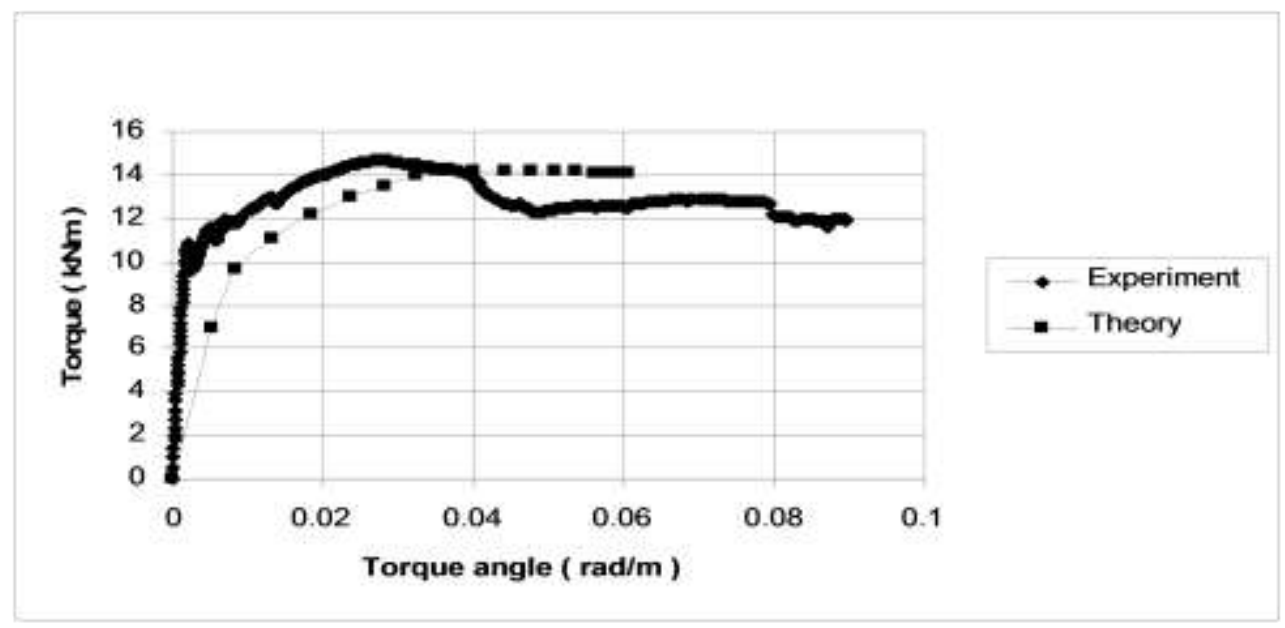

Figure 11. Comparison Result of the Beam B4HS

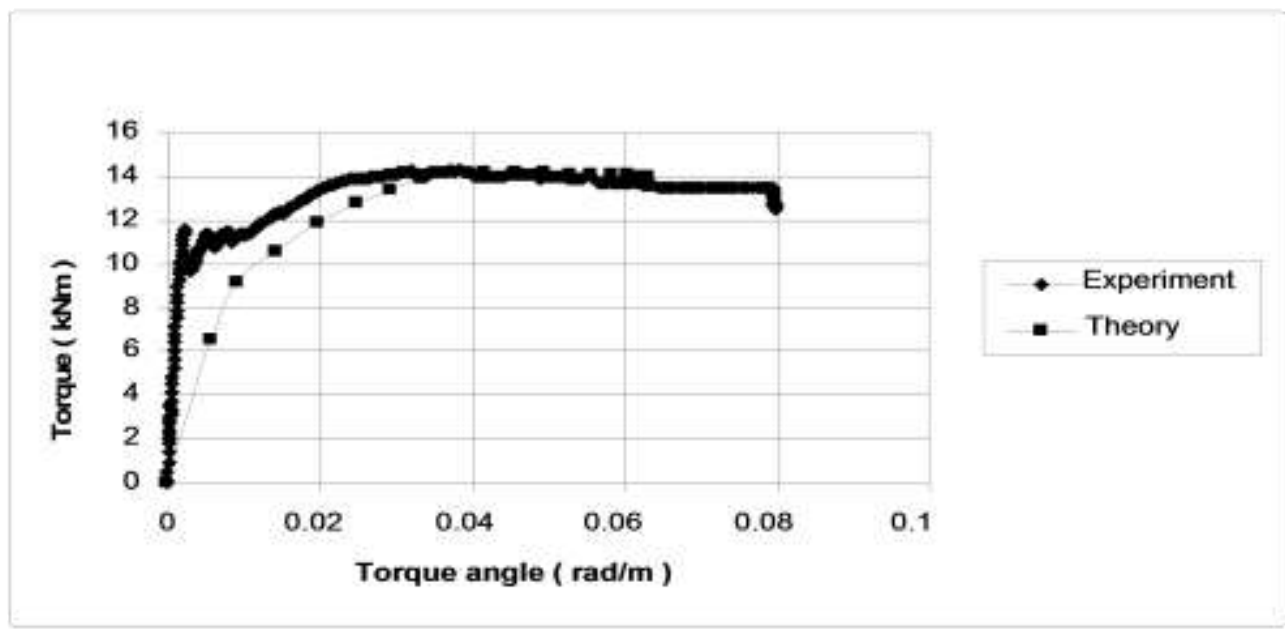

Figure 12. Comparison Result of the Beam B4HOD1

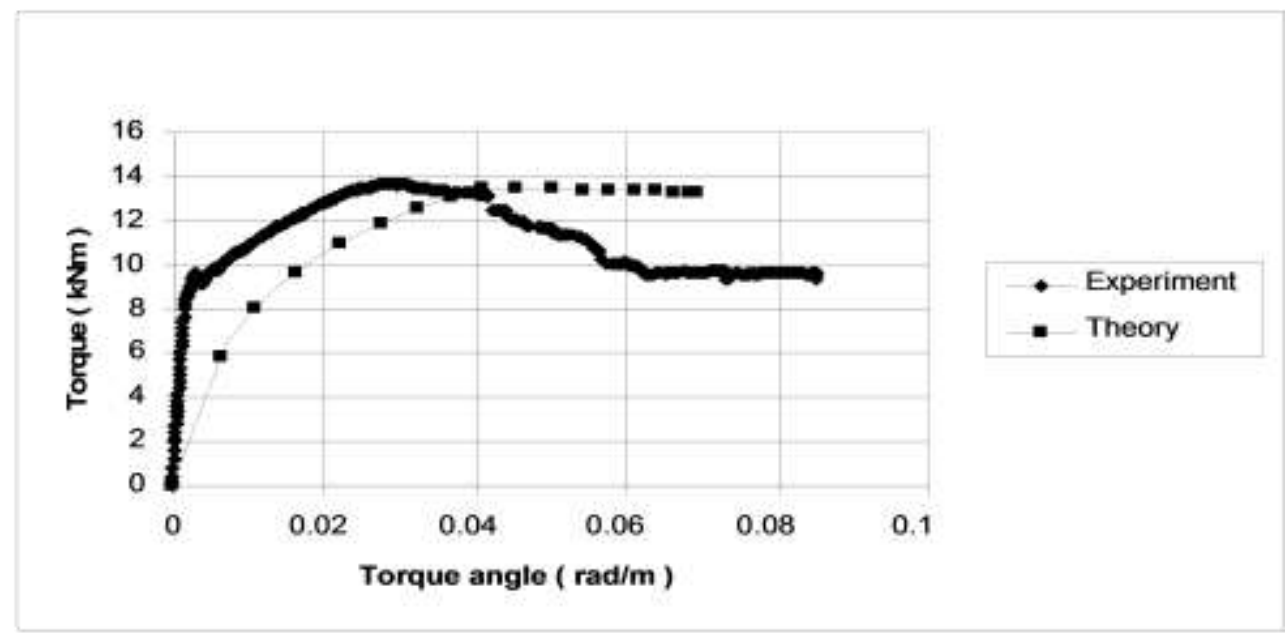

Figure 13. Comparison Result of the Beam B4HO 


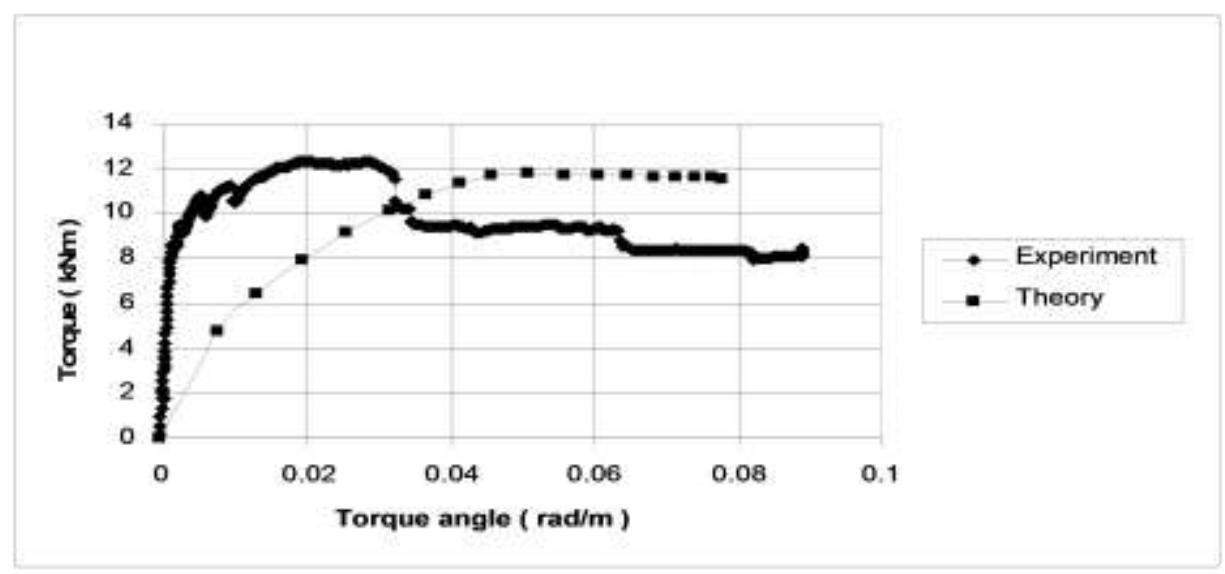

Figure 14. Comparison Result of the Beam B4HOD3

Table 2 shows that the softened truss model can accurately predict the maximum torque capacity of RC hybrid deep T-beam.

The comparison of the twist angle at maximum torque obtained using the softened truss model with the experimental results can be seen in Table 3 .

Table 3. Comparison the Maximum Twist Angle

\begin{tabular}{cccccc}
\hline Number & Beam & $\begin{array}{c}\theta_{\text {ult }}(\mathrm{anl} .) \\
\left(\mathrm{x} 10^{-3} \mathrm{rad} / \mathrm{m}\right)\end{array}$ & $\begin{array}{c}\theta_{\text {ult }}(\mathrm{exp} .) \\
\left(\mathrm{x} 10^{-3} \mathrm{rad} / \mathrm{m}\right)\end{array}$ & $\begin{array}{c}\theta_{\text {ult(anl) }} / \mathrm{D}_{\text {ult(exp })} \\
\text { rences } \\
(\%)\end{array}$ \\
\hline 1 & B4HS & 38.21971 & 28.152 & 1.358 & 35.8 \\
2 & B4HOD1 & 40.38389 & 32.301 & 1.250 & 25.0 \\
3 & B4HO & 44.14396 & 29.226 & 1.510 & 51.0 \\
4 & B4HOD3 & 50.33863 & 21.436 & 2.348 & 134.8 \\
\hline
\end{tabular}

$\theta_{\text {ult }}(\mathrm{anl}$.$) : the maximum twist angle based on the softened$ truss model

$\theta_{\text {ult }}$ (exp.): the maximum twist angle based on the experimental program

Table 3 shows that the maximum twist angle predicted by the theory is higher than the experimental result. It means that twist angle predicted by the theory gives more excessive twist angle than the experimental results, especially for the beam with the large opening. It is suspected, this softer behavior is due to the fact that the proposed method was derived based on the assumption that the concrete of the beam was already crack, while in reality the beam has two behavior condition throughout the loading history that is before first cracking and after cracking of the concrete.

\section{Conclusion}

Based on comparison of the results between analytical method and experimental program, the following conclusions can be drawn. The softened truss model can predict not only the torsional strength of the RC hybrid deep-T beam, but also the angle of twist throughout the post-cracking loading history.

Prediction of the maximum torque capacity of the RC hybrid deep T-beams based on the softened truss model is close to the experimental results. However, the twist angle predicted by the softened truss model is higher than to the experimental results, especially for the beam with large opening. The excessive prediction of the twist angle is due to the fact that the softened truss model was derived based on the assumption that the concrete of the beam was already crack, while in reality the beam has two behavior condition throughout the loading history, that are before first cracking and after first cracking of the concrete.

\section{Acknowledgement}

The first author would like to thank Professor Mohamad Sahari Besari, Professor Ridwan Suhud and Biemo Wuryanto Soemardi, Ph.D. for their kind assistance to the author during his study for Doctoral degree in Institut Teknologi Bandung (ITB), Indonesia. The first author also thanks the Laboratory of Structures and Materials, Civil Engineering Department of ITB, and the Laboratory of Structural Mechanics of the Inter University Research Center of ITB for the use of their research facilities.

\section{References}

1. Alwis, W.A.M., Mansur, M.A., Torsional Strength of RC Beams Containing Rectangular Openings, Journal of Structural Engineering, ASCE, 113 (11), 1987, pp. 2248-2258.

2. Hsu, T.T.C., Mo, Y.L., Softening of Concrete in Torsional Members- Theory and Tests, ACI Journal Proceeding, 82(3), 1985, pp. 290-303. 
3. Hsu, T.T.C., Mo, Y.L., Softening of Concrete in Torsional Members-Design Recommendations, ACI Journal Proceeding, 82(4), 1985, pp. 443452.

4. Hsu, T.T.C., Softened Truss Model Theory for Shear and Torsion, ACI Structural Journal, 85 (6), 1988, pp. 624-635.

5. Hsu, T.T.C., Nonlinear Analysis of Concrete Membrane Elements, ACI Structural Journal, 88(5), 1991, pp. 552-561.

6. Hsu, T.T.C., Nonlinear Analysis of Concrete Torsional Members, ACI Structural Journal, 88 (6), 1991, pp. 674-682.

7. Hsu, T.T.C., Unified Theory of Reinforced Concrete, CRC Press Inc., Florida, 1993.

8. Ali, M.A., White, R.N., Toward a Rational Approach for Design of Minimum Torsion Reinforcement, ACI Structural Journal, 96(1), 1999, pp. 40-45.

9. ACI Committee 318, Building Code Requirements for Structural Concrete (ACI 318M-08) and Commentary, American Concrete Institute, Detroit, 2008.

10. Akhtaruzzaman, A.A., Hasnat, A., Torsion in Concrete Deep Beams with an Opening, ACI Structural Journal, 86(1), 1989, pp. 20-25.

11. Samman, T.A., Radain, T.A., Al-Harbi, M.N., Torsional Behavior of High Strength Concrete Deep Beams, Proceeding of Fourth International Symposium on the Utilization of High strength/High Performance Concrete, 3, Paris, 1996, pp. 1003-1008.

12. Lisantono, A, Besari, M.S., Suhud, R., Soemardi, B.W., The Effect of LWC Flanges and Web Opening on the Torsional Capacity of Reinforced Concrete Deep T-Beams, Proceeding of the Eighth East Asia-Pasific Conference on the Structural Engineering and Construction, Nanyang Technological University, Singapore, 2001, Paper No. 1349.

13. Lisantono, A., Besari, M.S., Suhud, R., Soemardi, B.W., The Effect of Web Opening Location on the Torsional Behavior of Reinforced Concrete Hybrid Deep T-Beams, Jurnal Teknik Sipil, Universitas Tarumanagara, 2, 2002, pp. 183194.
14. Lisantono, A., Besari, M.S., Suhud, R., Soemardi, B.W., Experimental Study on the Effect of Web Opening Location on the Behavior of Reinforced Concrete Hybrid Deep T-Beam Subjected to Pure Torsion-Various Location in the Vertical Direction, Media Teknik, Majalah Ilmiah Teknologi, Universitas Gadjah Mada, 4, 2002, pp. 1622.

15. Lisantono, A., Besari, M.S., Suhud, R., Soemardi, B. W., Experimental Investigation on the Effect of Web Opening Dimension on the Behavior of RC Hybrid Deep T-Beam Subjected to Pure Torsion, Jurnal Teknik Sipil, Institut Teknologi Bandung, 11(1), 2004, pp. 1-7.

16. Hsu, T.T.C., Torsion of Reinforced Concrete, Van Nostrand Reinhold Company, New York, 1984.

17. Vecchio, F.J., Collins, M.P., Stress-Strain Characteristics of Reinforced Concrete in Pure Shear, IABSE Colloquium on Advanced Mechanics of Reinforced Concrete, Final Report, International Association for Bridge and Structural Engineering, Zurich, 1981, pp. 211-225.

18. Belarbi, A., Hsu, T.T.C., Constitutive Laws of Softened Concrete in Biaxial Tension-Compression, Research Report UHCEE 91-2, Department of Civil and Environmental Engineering, University of Houston, Houston, 1991.

19. MacGregor, J.G., Wight, J.K., Reinforced Concrete Mechanics and Design, Prentice Hall, Pearson Education South Asia Pte Ltd, Singapore, 2005.

20. Comite Euro-International Du Beton, CEB-FIP Model Code 1990, Bulletin D'information, No. 213/214, Thomas Telford, Lausane, 1993.

21. Lampert, P., Thurlimann, B., Torsion Tests of Reinforced Concrete Beams, Report No. 6506-2, June, Institut fur Baustatik, Zurich, Switzerand, 1968.

22. Lampert, P., Thurlimann, B., Torsion-Bending Tests on Reinforced Concrete Beams, Report No. 6506-3, January, Institut fur Baustatik, Zurich, Switzerland, 1969

23. Lisantono, A., Studi Perilaku Torsi Murni Balok Tinggi-T Hybrid Beton Normal dan Ringan dengan Bukaan pada Badan, Disertasi, Institut Teknologi Bandung, 2004. 